$\mathrm{A} \int_{\cos } \mathrm{H}$

Article history :

Received : 18.02.2014

Revised : 18.03.2015

Accepted : 04.04.2015
Members of the Research Forum

Associated Authors:

${ }^{1}$ Department of Seed Science and

Technology, College of Agriculture,

University of Agricultural Sciences, RAICHUR (KARNATAKA) INDIA
Author for correspondence : P.R. ARVINDKUMAR

Department of Seed Science and Technology, College of Agriculture, University of Agricultural Sciences, RAICHUR (KARNATAKA) INDIA Email : arvindkrathod09

@ gmail.com
THEASIAN JOURNALOF HORTICULTURE

Volume 10 | Issue 1 | June, 2015 | 26-30

Visit us -www.researchjournal.co.in

\title{
Effect of NAA, triacontonol and boron on seed longivity of bitter gourd (Momordica charantia L.) cV. PUSA VISESH
}

\section{P.R. ARVINDKUMAR, S.N. VASUDEVAN ${ }^{1}$ AND M.G. PATIL ${ }^{1}$}

ABSTRACT : Present investigation was carried out to study the effect of NAA, triacontanol and boron on seed longevity of bitter gourd cv. PUSA VISESH at College of Agriculture, Raichur. Seed obtained from the vine plants imposed with treatment NAA (25 and $50 \mathrm{ppm})$, triacontanol $(0.5$ and $1.0 \mathrm{ppm})$, boron $(3.0$ and $4.0 \mathrm{ppm})$ water spray and absolute control were used for foliar application at two to four true leaf stage followed by a interval of 60, 75 and 90 days after sowing in the Seed Technology Field Block, University of Agricultural Sciences, Raichur. Results revealed that the moisture content increased gradually as storage period increased in all the treatments. Seeds were stored in cloth bags under ambient storage condition and seed quality was tested after every month upto end of storage period (February, 2010 - January, 2011). Boron at 4 ppm maintained lower moisture content of seed $(7.07 \%, 7.19 \%$ and $9.16 \%)$ after first, third and twelve months after storage, respectively. Similarly boron at $4 \mathrm{ppm}$ recorded highest seed germination $(88.50 \%, 91.00 \%$ and $85.50 \%)$ and dehydrogenase activity $(0.350,0.431$ and 0.359 OD values) at the end of first, third and twelve months after storage, respectively.

KEY WORDS : Bitter gourd, Boron, Dehydrogenase enzyme activity

HOW TO CITE THIS ARTICLE : Arvindkumar, P.R., Vasudevan, S.N. and Patil, M.G. (2015). Effect of NAA, triacontonol and boron on seed longivity of bitter gourd (Momordica charantia L.) cv. PUSA VISESH. Asian J. Hort., 10(1) : 26-30. 